\title{
Prevalence of intestinal parasitosis and associated factors among the elderly
}

Patrícia Honório Silva Santos' Rita de Cássia Santos Barros' Kátia Virgínia Galvão Gomes² Adriana Alves Nery' Cezar Augusto Casotti

\section{Abstract}

Objective: To identify the prevalence of intestinal parasitosis and associated factors in elderly persons resident in the community. Methods: A cross-sectional study was performed involving 236 elderly persons in Aiquara, in the state of Bahia, Brazil, in 2015. Data were collected through a coprological survey and a questionnaire for information relating to sociodemographic characteristics, health and lifestyle. The presence of parasites in stools was verified by the Hoffman method. Results: The prevalence of intestinal parasites among the elderly was $30.5 \%$. Among infected elderly persons, $26.3 \%$ had monoparasitism, 3.8\% biparasitism and $0.4 \%$ polyparasitism. There was a predominance of protozoa $(80.8 \%)$ over helminths (19.2\%). The most prevalent parasites were Entamoeba coli (44.6\%); Endolimax nana $(21.7 \%)$ and Iodamoeba bütschlii (14.5\%). In the population studied, the independent variables analyzed were not associated $(p>0.05)$ with the presence of intestinal parasites. Conclusion: the prevalence of intestinal parasitic infections in elderly people living in the urban area of the municipal region of Aiquara, Bahia, was high and there was no association between intestinal parasites and sociodemographic characteristics, lifestyle or health.

\footnotetext{
Universidade Estadual do Sudoeste da Bahia, Programa de Pós-graduação em Enfermagem e Saúde. Jequié, BA, Brasil.

2 Centro de Referência em Doenças Endêmicas Pirajá da Silva, Setor de Bioquímica, Parasitologia e Imunologia.. Jequié, BA, Brasil.
}

Research funding: Ministry of Health, SUS Research Program (PPSUS), the State of Bahia Research Support Foundation (FAPESB) (SUS0055/2013).

Correspondence

Patrícia Honório Silva Santos

E-mail: patyhonorios@hotmail.com
Keywords: Elderly. Parasitic Diseases. Prevalence. 


\section{INTRODUCTION}

The technological and scientific advances linked to greater control over health, the environment, basic sanitation, and improvements in access to health services that have occurred in recent decades have contributed to an increase in life expectancy and, consequently, an aging population ${ }^{1}$. These changes have altered the health profile of the population, with a reduction in deaths from infectious diseases and an increase in noncommunicable diseases. However, despite the significant reduction in mortality caused by infectious-parasitic diseases, such illnesses still have a great impact on morbidity ${ }^{2}$.

Parasitic infections are caused by helminths and protozoa that colonize the intestines of vertebrates, and represent a major public health problem. They are geographically widely distributed, occurring in urban and rural areas, with variations depending on the environment and species of parasite involved ${ }^{3}$.

According to data from the Department of Informatics of the Sistema Único de Saúde (the Unified Health System) (DATASUS), infectious and parasitic diseases represented the sixth biggest cause of morbidity in Brazil in 2014, totaling 776,358 hospitalizations and corresponding to $7.28 \%$ of hospital morbidity in the period. In Bahia, this proportion was even higher, with such diseases accounting for $10.33 \%$ of hospitalizations, making them the third biggest cause of hospital morbidity in the state, ahead of diseases of the circulatory system ${ }^{4}$.

Although studies of intestinal parasitic diseases among the elderly population are limited because of the low relevance of this problem to this population, it is known that enteroparasite infections impair the nutritional status of such individuals through intestinal obstruction, malnutrition, anemia, diarrhea and malabsorption ${ }^{5,6}$, which can result in impaired functional capacity, autonomy and reduced quality of life among this age group.

The elderly are more likely to be predisposed to these diseases than young people, due to the decline in their immune system functions, which occur naturally during the aging process ${ }^{5}$. The progressive decline of independence in self-care is also a factor, and results in the impairment of personal hygiene and feeding ${ }^{1}$.
In this context, the present study aimed to identify the prevalence of intestinal parasitosis and associated factors in elderly residents living in the community.

\section{METHODS}

An analytical, cross-sectional epidemiological study was carried out based on data from a population-based household survey, entitled: Saúde e estilo de vida de idosos (the Health and lifestyle of the Elderly), which took place in Aiquara, in the state of Bahia, in Brazil.

The municipal region of Aiquara is located in the south-central region of the state of Bahia, and has a Human Development Index (HDI) of 0.583 and a Gini Index of 0.4393. According to data from the Intituto Brasileiro de Geografia e Estatística (the Brazilian Institute of Geography and Statistics) (IBGE), 100\% of urban areas possess water supply, garbage collection and sewerage ${ }^{7}$.

A census of the elderly population living in the urban area of the municipal region of Aiquara was carried out, and 379 elderly people were identified. Of these, 236 individuals aged 60 years and above, of both genders, who were not institutionalized and who slept at least three nights at home in the urban area, agreed to participate in the study and met the inclusion criteria, which were be able to respond to the questionnaire, collect stool specimens, and be located in at least one of three attempts at different times of the day. All participants signed a Free and Informed Consent Form (FICF) and elderly persons who did not meet these criteria were excluded from the study ( $\mathrm{n}=143)$.

Data were collected between January and August 2015 by previously trained undergraduate and postgraduate students from the area of health. Initially, a questionnaire compiled from validated instruments was used to obtain information on sociodemographic characteristics, health conditions and lifestyle, and a blood test and cropological survey were carried out.

For the analysis, the presence of intestinal parasitosis, categorized as present or absent, was identified as a dependent variable through the parasitological examination of feces, using the 
Hoffman method, based on a single sample provided by the elderly. Prior to the collection of fecal material, the elderly were advised to collect a fresh stool sample and informed that there were no prior food restrictions to be followed. They were also given a pot with a screw cap for storage. These samples were properly handled and transported, and a fresh specimen underwent laboratory diagnosis at the laboratory of the Centro de Referência em Doenças Endêmicas Pirajá da Silva (Laboratory of the Pirajá da Silva Reference Center on Endemic Diseases (PIEJ), in the municipal region of Jequié, Bahia, Brazil.

The sociodemographic conditions were evaluated through the variables gender, which was categorized into male and female; age group, which was divided into 60-69 years, 70-79 years and 80 years or more; skin color, which was defined as white or non-white (brown, black and yellow/Asian-Brazilian); living arrangement (lives alone or lives with other(s)); education (illiterate/can read and write, elementary and high school); income (up to one minimum salary and $>1$ minimum salary, considering the value of the minimum salary at the time (788 reais)) and currently working (referring to any paid productive activity), categorized as yes or no.

To analyze lifestyle, the variables alcohol consumption and smoking, both categorized as yes and no, were used.

Health condition was evaluated through Body Mass Index (BMI), Waist Circumference (WC), indigestion and lack of appetite in the last 30 days, anemia and functional capacity

BMI was obtained from the ratio between body mass $(\mathrm{BM})$ in kilograms and height $(\mathrm{H})$ in meters squared $\left[\mathrm{BMI}=\mathrm{BM}(\mathrm{kg}) / \mathrm{H}^{2}(\mathrm{~m})\right]$. A portable digital scale was used to measure body mass, and the elderly were asked to wear light clothes and be barefoot. In order to evaluate height, a portable stadiometer was used, with the elderly individuals instructed to go barefoot and stand in an orthostatic position, with their feet together and the posterior surfaces of their heels, buttocks, head and shoulders in contact with the wall, following the guidelines of The Frankfurt Plane. Both measurements were performed in duplicate and the mean values were used in the analyzes. For analysis, BMI was categorized as underweight $(\mathrm{BMI}<22)$, normal weight (BMI of 22-27) and overweight $\left(\mathrm{BMI}>27 \mathrm{Kg} / \mathrm{m}^{2}\right)^{8}$.

Waist circumference was measured with a 2 meter long flexible and inextensible anthropometric tape, which was positioned at the height of the navel. The measurements were taken in duplicate and the mean value was used to categorize the elderly as normal (WC $<80 \mathrm{~cm}$ for women and $<94 \mathrm{~cm}$ for $\mathrm{men}$ ), and elevated (WC $\geq 80 \mathrm{~cm}$ for women and $\geq 94 \mathrm{~cm}$ for men) ${ }^{9}$.

Indigestion and a lack of appetite in the last 30 days were obtained through two questions from the Self-Report Questionnaire (Srq-20) $)^{10}$, categorized as yes or no.

Anemia was assessed via circulating hemoglobin $(\mathrm{Hb})$ concentration in grams per deciliters $(\mathrm{g} / \mathrm{dL})$. For analysis, data were categorized in accordance with criteria established by the World Health Organization (WHO) as anemia $(\mathrm{Hb}<12 \mathrm{~g} / \mathrm{dL}$ for women and $\mathrm{Hb}<13 \mathrm{~g} / \mathrm{dL}$ for men $)^{11}$ and nonanemia. The collection of blood for hemogram analysis was previously scheduled and was carried out at the Municipal Health Department by trained and experienced laboratory technicians. The elderly persons were seated with their arm in a horizontal position, and venipuncture was performed in the median ulnar vein, in the ulnar fossa, following tourniquet. A vacuum collection system in a tube containing ethylenediaminetetraacetic acid anticoagulant (EDTA $\mathrm{K}_{2}$ ) was used. The blood samples were properly handled and transported to the PIEJ Laboratory, where they were processed and analyzed.

Functional ability was assessed through the Basic Activities of Daily Living (BADL) questionnaire ${ }^{12}$ in its transcutural adaptation ${ }^{13}$ and the Instrumental Activities of Daily Living (IADL) questionnaire ${ }^{14}$ adapted to the Brazilian context ${ }^{15}$. As proposed by Hoyemans et al. ${ }^{16}$, a scale of hierarchical functional disability was constructed, divided into three categories: independent; dependent in IADL and dependent in BADL and IADL, with those who reported dependence in BADL but not in IADL considered dependent in both dimensions. Elderly 
people who reported difficulty in one or more activities were considered dependent, and those who did not describe such difficulties were considered independent.

To analyze the data, descriptive analysis was performed through the distribution of absolute and relative frequencies, mean, standard deviation and amplitude. The association between intestinal parasitosis and the independent variables was tested using bivariate logistic regression. It was not possible to perform adjusted analysis as the independent variables analyzed did not reach the criterion of significance $(p<0.20)$ for inclusion in the adjusted model.
The study met ethical requirements, and was approved by the Ethics Research Committee of the Universidade Estadual do Sudoeste da Bahia (State University of South East Bahia), CAAE:10786212.3.0000.0055.

\section{RESULTS}

A total of 236 elderly people participated in the study, of whom $132(55.9 \%)$ were female and $104(44.1 \%)$ were male. The age of the population ranged from 60 to 95 years, with a mean age of $71.54 \pm 7.62$ years. The other characteristics of the studied population are described in table 1 .

Table 1. Characteristics of study population. Aiquara, Bahia, Brazil, 2015.

\begin{tabular}{|c|c|c|}
\hline Variables & Response $(\%)$ & $\mathrm{N}(\%)$ \\
\hline Age group (years) & 100 & \\
\hline $60-69$ & & $97(41.1)$ \\
\hline $70-79$ & & $97(41.1)$ \\
\hline$\geq 80$ & & $42(17.8)$ \\
\hline Skin color/ethnicity & 100 & \\
\hline White & & $29(12.3)$ \\
\hline Non-white & & $207(87.7)$ \\
\hline Living arrangements & 100 & \\
\hline Live alone & & $47(19.9)$ \\
\hline Live with other(s) & & $189(80.1)$ \\
\hline Schooling & 97.5 & \\
\hline Illiterate/can read and write & & $124(53.9)$ \\
\hline Elementary School & & $92(40.0)$ \\
\hline High School/Higher Education & & $14(6.1)$ \\
\hline Income (Minimum Salary) & 99.2 & \\
\hline Up to 1 & & $203(86.8)$ \\
\hline$>1$ & & $31(13.2)$ \\
\hline Currently working & 98.7 & \\
\hline $\operatorname{Sim}$ & & $38(16.3)$ \\
\hline No & & $195(83.7)$ \\
\hline Alcohol consumption & 100.0 & \\
\hline Yes & & $52(22.0)$ \\
\hline No & & $184(78.0)$ \\
\hline Smoking & 93.2 & \\
\hline Yes & & $22(10.0)$ \\
\hline No & & $198(90.0)$ \\
\hline
\end{tabular}


continued from Table 1

\begin{tabular}{|c|c|c|}
\hline Variables & Response $(\%)$ & $\mathrm{N}(\%)$ \\
\hline Body Mass Index $\left(\mathrm{Kg} / \mathrm{m}^{2}\right)$ & 88.1 & \\
\hline$<22$ & & $41(19.7)$ \\
\hline $22-27$ & & $76(36.5)$ \\
\hline$>27$ & & $91(43.8)$ \\
\hline Waist Circumference & 88.6 & \\
\hline Normal & & $61(29.2)$ \\
\hline Elevated & & $148(70.8)$ \\
\hline Indigestion & 99.6 & \\
\hline Yes & & $41(17.4)$ \\
\hline No & & $194(82.6)$ \\
\hline Lack of Appetite & 99.6 & \\
\hline Yes & & $78(33.2)$ \\
\hline No & & $157(66.8)$ \\
\hline Anemia & 99.2 & \\
\hline Present & & $30(12.8)$ \\
\hline Absent & & $204(87.2)$ \\
\hline Functional Capacity & 100.0 & \\
\hline Independent & & $79(33.5)$ \\
\hline Dependent in IADL & & $128(54.2)$ \\
\hline Dependent in BADL and IADL & & $29(12.3)$ \\
\hline
\end{tabular}

IADL: Instrumental Activities of Daily Living; BADL: Basic Activities of Daily Living.

Among the 236 elderly patients who underwent parasitological examination of feces, the prevalence of intestinal parasitosis was 30.5\%. Of these elderly, persons $26.3 \%$ suffered mono-parasitism; $3.8 \%$ biparasitism and $0.4 \%$ poly-parasitism (Figure 1).

The prevalence of intestinal parasitosis among the elderly is shown in Table 2 . There was a predominance of protozoa (80.8\%) in comparison to helminths $(19.2 \%)$ and eight types of parasites were detected, the most common being Entamoeba Coli (44.6\%); Endolimax nana (21.7\%) and Iodamoeba butscblii (14.5\%).

The species that presented the most interaction with others were Entamoeba coli and Iodamoeba butschlii, with the following associations identified: Entamoeba coli and Endolimax nana; Entamoeba coli and Iodamoeba butschlii; Ancylostomídeos and Iodamoeba butschlii; Entamoeba coli, Iodamoeba butscblii and Strongyloides stercoralis; and Entamoeba coli and Schistosoma mansoni.

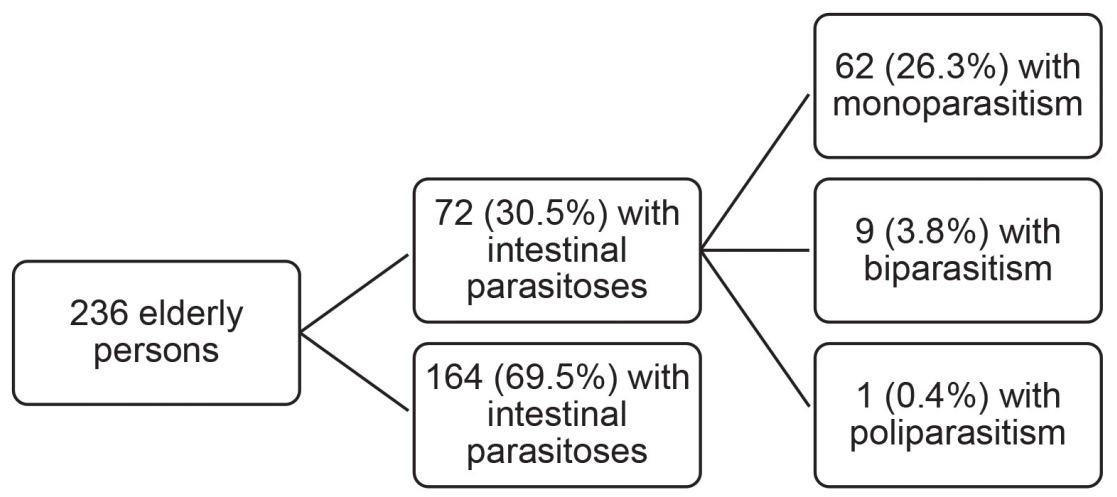

Figure 1. Profile of intestinal parasitosis among the elderly. Aiquara, Bahia, Brazil, 2015. 
Table 2. Frequency of intestinal parasites among the elderly. Aiquara, Bahia, Brazil, 2015.

\begin{tabular}{lc}
\hline Intestinal parasites & $\mathrm{N}(\%)$ \\
\hline Helminths & $5(6.0)$ \\
Schistosoma mansoni & $4(4.8)$ \\
\hline Ancylostomideos & $4(4.8)$ \\
\hline Strongyloides stercoralis & $2(2.4)$ \\
\hline Trichuristrichiura & $1(1.2)$ \\
\hline Enterobius vermicularis & \\
\hline Protozoa & $37(44.6)$ \\
Entamoeba coli & $18(21.7)$ \\
\hline Endolimax nana & $12(14.5)$ \\
\hline Iodamoeba butschlii & $83(100.0)$ \\
\hline Total &
\end{tabular}

Table 3 shows the prevalence of intestinal parasitosis among the elderly and their relationship with the independent variables of the study. Intestinal parasites were more frequent in elderly males, who lived alone and were illiterate. There was also a greater frequency of parasitosis among those with an income of up to one minimum wage, without a current job, who were underweight and had a normal WC, were anemic, reported a lack of appetite and were dependent for IADL. However, none of the variables were significantly associated $(p<0.05)$ with intestinal parasitosis.

Table 3. Prevalence of intestinal parasites among the elderly and relationship with the independent variables of the study. Aiquara, Bahia, Brazil, 2015.

\begin{tabular}{|c|c|c|c|c|}
\hline Variables & $\%$ & Crude OR & $\mathrm{CI} 95 \%$ & $p$-value \\
\hline \multicolumn{5}{|l|}{ Gender } \\
\hline Male & 32.7 & 1 & & \\
\hline Female & 28.8 & 0.83 & $0.48-1.45$ & 0.518 \\
\hline \multicolumn{5}{|l|}{ Age group (years) } \\
\hline $60-69$ & 27.8 & 1 & & \\
\hline $70-79$ & 29.9 & 1.11 & $0.59-2.06$ & 0.751 \\
\hline$\geq 80$ & 38.1 & 1.59 & $0.74-3.43$ & 0.231 \\
\hline \multicolumn{5}{|l|}{ Skin color/ethnicity } \\
\hline White & 31.0 & 1 & & \\
\hline Non-white & 30.4 & 0.97 & $0.42-2.25$ & 0.948 \\
\hline \multicolumn{5}{|l|}{ Living arrangements } \\
\hline Live alone & 36.2 & 1.38 & $0.70-2.20$ & 0.347 \\
\hline Live with other(s) & 29.1 & 1 & & \\
\hline \multicolumn{5}{|l|}{ Schooling } \\
\hline Illiterate/can read and write & 31.5 & 1.15 & $0.34-3.88$ & 0.826 \\
\hline Elementary School & 29.3 & 1.04 & $0.30-3.60$ & 0.953 \\
\hline High School/Higher Education & 28.6 & 1 & & \\
\hline \multicolumn{5}{|l|}{ Income (Minimum Salary) } \\
\hline Up to 1 & 32.0 & 1.61 & $0.66-3.94$ & 0.292 \\
\hline$>1$ & 22.6 & 1 & & \\
\hline
\end{tabular}


continued from Table 3

\begin{tabular}{|c|c|c|c|c|}
\hline Variables & $\%$ & Crude OR & $\mathrm{CI} 95 \%$ & $p$-value \\
\hline \multicolumn{5}{|l|}{ Currently working } \\
\hline Sim & 23.7 & 0.68 & $0.30-1.53$ & 0.352 \\
\hline No & 31.3 & 1 & & \\
\hline \multicolumn{5}{|l|}{ Alcohol consumption } \\
\hline Yes & 28.8 & 0.90 & $0.46-1.78$ & 0.768 \\
\hline No & 31.0 & 1 & & \\
\hline \multicolumn{5}{|l|}{ Smoking } \\
\hline Yes & 27.3 & 0.86 & $0.32-2.31$ & 0.769 \\
\hline No & 30.3 & 1 & & \\
\hline \multicolumn{5}{|l|}{ Body Mass Index $\left(\mathrm{Kg} / \mathrm{m}^{2}\right)$} \\
\hline$<22$ & 31.7 & 1.50 & $0.64-3.48$ & 0.350 \\
\hline $22-27$ & 23.7 & 1 & $0.64-2.59$ & 0.476 \\
\hline$>27$ & 28.6 & 1.29 & & \\
\hline \multicolumn{5}{|l|}{ Waist Circumference } \\
\hline Normal & 32.8 & 1 & & \\
\hline Elevated & 25.7 & 0.71 & $0.37-1.36$ & 0.298 \\
\hline \multicolumn{5}{|l|}{ Indigestion } \\
\hline Yes & 29.3 & 0.92 & $0.44-1.93$ & 0.834 \\
\hline No & 30.9 & 1 & & \\
\hline \multicolumn{5}{|l|}{ Lack of Appetite } \\
\hline Yes & 35.9 & 1.44 & $0.81-2.57$ & 0.219 \\
\hline No & 28.0 & 1 & & \\
\hline \multicolumn{5}{|l|}{ Anemia } \\
\hline Present & 36.7 & 1.36 & $0.61-3.03$ & 0.455 \\
\hline Absent & 29.9 & 1 & & \\
\hline \multicolumn{5}{|l|}{ Functional Capacity } \\
\hline Independent & 25.3 & 1 & & \\
\hline Dependent in IADL & 35.2 & 1.60 & $0.86-2.98$ & 0.140 \\
\hline Dependent in BADL and IADL & 24.1 & 0.94 & $0.35-2.53$ & 0.900 \\
\hline
\end{tabular}

IADL: Instrumental Activities of Daily Living; BADL: Basic Activities of Daily Living; $p$-value: Wald Test.

\section{DISCUSSION}

The present study identified a high prevalence of intestinal parasitosis in community-dwelling elderly people (30.5\%), corroborating international and national studies which also evaluated community based populations, such as that by Chen et al. ${ }^{17}$, which verified a prevalence of $30.7 \%$ in a study of 493 Chilean elderly persons, and that of Furtado and $\mathrm{Melo}^{18}$, which identified a higher prevalence (40.5\%) in Parnaíba, in the state of Piaui.
The high prevalence of intestinal parasitosis among the elderly can be explained by the immunological deficiencies that occur with aging, increasing susceptibility to such diseases ${ }^{5}$. Associated with this are factors such as the use of polypharmacy, which exposes the elderly to drug interactions, further assaulting the body's defense system; increased difficulty in performing self-care, which impairs personal hygiene and feeding ${ }^{1}$ and causes a possible disconnect of elderly people from their health ${ }^{18}$. 
It is worth mentioning that many elderly people perform activities that require contact with the soil, such as gardening and yard cleaning, which facilitate contamination by increasing the risk of exposure to parasites ${ }^{19}$. These findings may explain the high prevalence of parasitic diseases in the analyzed municipal region, which is a small town with few economic options where many elderly persons are involved in labor activities related to agriculture.

In addition, the prevalence of intestinal parasitosis in the elderly is influenced by geographic, cultural, ethnic and behavioral issues ${ }^{20}$, increasing in places where living conditions and basic sanitation are precarious or even non-existent ${ }^{21}$. Although $100 \%$ of households in Aiquara are covered by a water supply, sewage network and garbage collection, $63.7 \%$ of the population lives on an income of less than half the minimum wage and $41.4 \%$ have a schooling level of incomplete elementary education ${ }^{22}$.

In the present study, of the elderly infected with intestinal parasites, $26.3 \%$ presented monoparasitism, 3.8\% bi-parasitism and $0.4 \%$ polyparasitism. Other studies, conducted both in geriatric care facilities ${ }^{3}$ and in the community ${ }^{19}$, was also found that mono-parasitism is the most common condition among the elderly, followed by bi-parasitism and poly-parasitism.

It is noteworthy that parasites that affect individuals in isolation do not generally possess high lethality. The associated infections, however, including isolated infections, affect the nutritional state of the individual, interfering and competing with the absorption of the nutrients, potentially causing intestinal bleeding, and increasing the chance of complications ${ }^{3}$.

In the present study, the prevalence of protozoa $(80.8 \%)$ was higher than that of helminths $(19.2 \%)$, a finding also evidenced in other studies ${ }^{20,23}$. These values can be justified by the precarious conditions of sanitation and education present in poor communities ${ }^{20}$.

As other studies have also shown, ${ }^{5,23}$ nonpathogenic parasites such as Entamoeba coli and Endolimax nana were the most prevalent. Although they do not represent health problems, they reveal a deficiency in hygienic issues such as hand washing after using the toilet and before meals, contaminating food and water with fecal material, leaving the elderly susceptible to pathogens ${ }^{5,24}$.

Although some studies have identified an association between intestinal parasitosis in the elderly and socioeconomic factors $\left(\right.$ age $^{5}$, marital status, education and income $\mathrm{e}^{25}$ ) and health conditions (activities of daily living ${ }^{25}$ ), in the present study, no association was found with these groups of variables, although it was observed that older elderly people $(\mathrm{OR}=1.59)$, who live alone $(\mathrm{OR}=1.38)$, were illiterate or can read and write $(\mathrm{OR}=1.15)$, anemic $(\mathrm{OR}=$ 1.36), who reported a lack of appetite $(\mathrm{OR}=1.44)$ or were dependent for IADL $(\mathrm{OR}=1.60)$ were more likely, although not significantly so, to be affected by intestinal parasitosis.

There was also no significant association with tobacco and alcohol consumption, which reinforces the idea that environmental hygiene and health education are the main determinants of parasitic infections in the population. These variables may have functioned as confounding variables.

Corroborating the findings of the present study, a study of elderly people in Porto Alegre, Rio Grande do Sul, also found no significant association between parasitic diseases and socioeconomic, demographic and health variables, with the exception of arterial hypertension and mental problems, which were not considered in the present study. In contrast, an association with hygienic and sanitary variables was verified $^{26}$, which were also not analyzed by this study.

The high prevalence of intestinal parasitosis among the elderly verified in the present study reveals the clinical and epidemiological importance of this condition, demonstrating that it remains a major public health issue, including among older age groups. Although some authors suggest that children are the most vulnerable to this problem ${ }^{27,28}$, this comparison could not be tested in the present study as the sample did not include this population group. However, considering the magnitude of this health problem among the elderly population, studies on the prevalence of parasitosis in other population groups are necessary. 
Shakya et al. ${ }^{29}$ indicated that intestinal parasites represent a threat for elderly people living in underdeveloped regions. Therefore, the present study warns of the need to investigate parasitic diseases in the elderly population, allowing the magnitude of the problem to be identified, and appropriate therapeutic measures to be adopted. In addition, the results of this study can be used by health authorities to guide the creation of public and social policies that improve socioeconomic, health and educational conditions, reflecting the health and quality of life of the elderly population.

Limitations of the present study include the fact that housing conditions, sanitary facilities, the destination of human waste, garbage collection, water and sewage treatment, hand washing, use of shoes and consumption of fruit and vegetables were not investigated. These factors are possibly related to the high prevalence of parasitic diseases in the elderly. A further limitation is the fact that only one stool sample was collected from each elderly person. When repeated negative fecal examinations can become positive, as in some cases positivity depends on the dynamics of the detectable stages. This may have resulted in an underestimation of the prevalence of intestinal parasitosis among the elderly found in this study.

\section{REFERENCES}

1. Matos AS, Murai HC. Prevalência de parasitoses intestinais por helmintos e protozoários em idosos. Rev Enferm UNISA. 2005;6:9-14.

2. Araújo JD. Polarização epidemiológica no Brasil. Epidemiol Serv Saúde. 2012;21(04):533-38.

3. Macharetti H, Norberg NA, Martins JSA, Oliveira JTM, Santa Helena AA, Maliska C, et al. Protozoários e helmintos em interação com idosos albergados em lares geriátricos no Estado do Rio de Janeiro, Brasil. Rev UNIABEU. 2014;7(16):103-12.

4. BRASIL. Departamento de Informática do Sistema Único de Saúde [Internet]. Brasília, DF: DATASUS; 2008- . Morbidade Hospitalar do SUS - Brasil; 2015 [acesso em 16 nov. 2015]. Disponível em: http://tabnet. datasus.gov.br/cgi/deftohtm.exe?sih/cnv/nruf.def

\section{CONCLUSION}

In community-dwelling elderly people in the urban area of Aiquara, Bahia, the prevalence of intestinal parasitosis was found to be high. Among the infected elderly, those with mono-parasitism were most prevalent, followed by bi-parasitism and poly-parasitism. In terms of parasites, protozoa predominated over helminths. In the evaluated population there was no significant association between intestinal parasitosis and socio-demographic characteristics, lifestyle and health conditions.

The results of the present study demonstrate the profile of intestinal parasitosis in the elderly in a small town, highlighting its high prevalence and the necessity of adopting prevention and control measures on the part of administrators, health professionals and the community through improvements in living conditions and hygiene habits, such as washing hands before meals and following the use of the toilet, as well as respecting proper food hygiene.

\section{ACKNOWLEDGEMENTS}

The authors would like to thank the team of the Pirajá da Silva Reference Center on Endemic Diseases (PIEJ).

5. Ely LS, Engroff P, Lopes GT, Werlang M, Gomes I, De Carli GA. Prevalência de enteroparasitos em idosos. Rev Bras Geriatr Gerontol. 2011;14(4):637-46.

6. Larré AB, Bürgie CD, Engroff P, De Carli GA. Prevalência de parasitoses em idosos residentes e trabalhadores de instituições de longa permanência na região metropolitana de Porto Alegre e na região serrana do Rio Grande do Sul. Mundo Saúde. 2015;39(1):84-91.

7. Instituto Brasileiro de Geografia e Estatística [Internet]. Rio de Janeiro: IBGE; [1995- ]. Cidades; 2016 [acesso em 04 jul. 2016]. Disponível em: http:// cidades.ibge.gov.br/xtras/perfil.php?lang=\&codmun =290060\&search=bahia $\mid$ aiquara . 
8. American Academy of Family Physicians, American Dietetic Association, National Council on the Aging. Nutrition screening e intervention resources for healthcare professionals working with older adults. Nutrition Screening Initiative [Internet]. Washington: American Dietetic Association; 2002.

9. Han TS, Van Lee EM, Seidell JC, Lean MEJ. Waist circumference action levels in the identification of cardiovascular risk factors: prevalence study in a random sample. Br Med J. 1995:311:1401-5.

10. Gonçalves DM, Stein AT, Kapczinski F. Avaliação de desempenho do Self-Reporting Questionnaire como instrumento de rastreamento psiquiátrico: um estudo comparativo com o Structured Interview for DSMIV-TR. Cad Saúde Pública. 2008;24(2):380-90.

11. World Health Organization. Worldwide prevalence of anaemia 1993-2005: WHO global database on anemia. Geneva: WHO; 2005.

12. Katz S, Ford AB, Moskowitz RW, Jackson BA, Jaffe MW. Studies of illness in the aged. The index of ADL: a standardized measure of biological and psychosocial function. JAMA. 1963;185:914-9.

13. Lino VTS, Pereira SEM, Camacho LAB, Ribeiro Filho ST, Buksman S. Adaptação transcultural da Escala de Independência em Atividades da Vida Diária (Escala de Katz). Cad Saúde Pública. 2008;24(1):103-12.

14. Lawton MP, Brody EM. Assesment of older people: self-maintaining and instrumental activities of daily living. Gerontologist. 1969;9(3 part 1):179-86.

15. Santos RL, Virtuoso Júnior JS. Confiabilidade da versão brasileira da escala de atividades instrumentais da vida diária. Rev Bras Promoç Saúde. 2008;21(4):290-6.

16. Hoeymans N, Feskens EJ, Van den Bos GA, Kromhout D. Measuring functional status: crosssectional and longitudinal associations between performance and self-report (Zutphen Elderly Study 1990-1993). J Clin Epidemiol. 1996;49(10):1103-10.

17. Chen SH, Codoceo A, Carrasco O, Torres YM. Enteroparasitosis en la poblacion de la tercera edad consultante en centros medicos de la Pontificia Universidad Catolica de Chile, 1997. Parasitol Día. 1998;22(34):114-6.

18. Furtado LFV, Melo ACFL. Prevalência e aspectos epidemiológicos de enteroparasitoses na população geronte de Parnaíba, Estado do Piauí. Rev Soc Bras Med Trop. 2011;44(4):513-5.
19. Hurtado-Guerrero AF, Alencar FH, HurtadoGuerrero JC. Ocorrência de enteroparasitas na população geronte de Nova Olinda do NorteAmazonas, Brasil. Acta amaz. 2005;35(4):487-90.

20. Santos CS, Souza PSA, Frizzo MN, Mallet EKV, Pedroso D. Prevalência de enteroparasitoses e sua relação com eosinofilia e anemia em pacientes do município de Santo Ângelo, Rio Grande do Sul, Brasil. Rev Saúde Integ. 2015;6(11-12):293-307.

21. Andrade ED, Leite ICG, Rodrigues VDO, Cesca MG. Parasitoses intestinais: uma revisão sobre seus aspectos sociais, epidemiológicos, clínicos e terapêuticos. Rev APS. 2010;13(2):231-40.

22. Brasil. Departamento de Informática do Sistema Único de Saúde [Internet]. Brasília, DF: DATASUS; 2008. Informações da Saúde. Demográficas e socioeconômicas; 2016 [acesso em 04 jul. 2016]. Disponível em: http://www2.datasus.gov.br/ DATASUS/index.php?area $=0206$.

23. Almeida F, Silva R, Medeiros J. Ocorrência de helmintos e protozoários intestinais em idosos. J Biol Pharm Agric Manage. 2015;10(2):78-82.

24. Lima Junior OAD, Kaiser J, Catisti R. High occurrence of giardiasis in children living on a'landless farm workers' settlement in Araras, São Paulo, Brazil. Rev Inst Med Trop São Paulo. 2013;55(3):185-8.

25. Naves MM, Costa-Cruz JM. High prevalence of Strongyloides stercoralis infection among the elderly in Brazil. Rev Inst Med Trop São Paulo. 2013;55(5):309-13.

26. Engroff P. Prevalência de infecções enteroparasitárias e soroprevalência de Toxoplasma Gondii em idosos atendidos pela Estratégia Saúde da Família de Porto Alegre [tese]. Rio Grande do Sul: Pontifícia Universidade Católica do Rio Grande do Sul; 2014.

27. Lodo M, Oliveira CGBD, Fonseca ALA, Caputto LZ, Packer MLT, Valenti VE, et al. Prevalência de enteroparasitas em município do interior paulista. Rev Bras Crescimento Desenvolv hum. 2010;20(3):769-77.

28. Gonçalves ALR, Belizário TL, Pimentel JDB, Penatti MPA, Pedroso RDS. Prevalence of intestinal parasites in preschool children in the region of Uberlândia, State of Minas Gerais, Brazil. Rev Soc Bras Med Trop. 2011;44(2):191-3.

29. Shakya B, Rai SK, Singh A, Shrestha A. Intestinal parasitosis among the elderly people in Kathmandu Valley. Nepal Med Coll J. 2006;8(4):243-70. 